\title{
The Level of Understanding towards Teachers Competency among Elementary School in Urban Areas of Yogyakarta
}

\author{
Vera Yuli Erviana ${ }^{1}$, Anik Ghufron ${ }^{2 *}$, Haryanto ${ }^{2}$ \\ ${ }^{1}$ Universitas Negeri Yogyakarta and Universitas Ahmad Dahlan, Indonesia \\ ${ }^{2}$ Universitas Negeri Yogyakarta, Indonesia
}

\begin{abstract}
Teacher competency is the most important thing every teacher in all areas must have including urban, urban, and rural ones. This study aims to describe the level of understanding of teacher competency among elementary school teachers in an urban area of Yogyakarta. This research belongs to descriptive research. It involved 56 teachers in urban areas of Yogyakarta chosen randomly as the research sample. The data collecting techniques used were questionnaires, interviews, and the RASCH WinstepsV3 model was used as the data analysis techniques. The results showed of understanding and mastery towards teacher competencies varied in which the professional and pedagogical competencies were categorized lower than that of the other two competencies i.e. social and personality. The professional competence aspects found lower were the abilities to understand theories of the elementary education foundation, to conduct research, and to conduct scientific thinking process. Meanwhile, the low pedagogical competence included aspects in understanding types of learning theory, using ICT in the learning process, and planning the learning. Based on these results, it's recommended that there's further training related to these competencies provided to them as these competencies have a great impact on their professionalism as teachers of elementary school level.
\end{abstract}

Keywords: Elementary school, Teachers competency, Urban area.

\section{INTRODUCTION}

The development of the education system is one of the major factors used in assessing the success of national development. The process of teaching and learning is one of the determining factors in the development of an education system. Efforts that can be made in creating and improving human resources can be pursued through education (Suryarahman \& Hastuti, 2014; Wilson, 2014). One who plays the main role in the world of education is teachers. Teachers become agents of change in determining the fate of young learners with their future. Elementary School Teachers particularly have a big role in improving the quality of education of the students. Elementary teachers are expected to be able to make changes, especially to arouse the students' enthusiasm in learning, which ultimately leads to a learning success (Okeke \& Mtyuda, 2017). Therefore, there's a strong call for the elementary teachers' competence so that these teachers can improve the quality of education, make changes, and develop their professionalism in teaching (Ball, 2000; Day, 2002). A teacher in digital era is someone regarded as the one who is consciously responsible for educating, teaching, and guiding the students in and outside the school to become human beings useful to the nation and state (Amin, 2016; Hamalik, 2008; Wiretna et al., 2020). Teachers are professional educators whose main tasks are of educating, teaching, guiding, directing, training, evaluating, and assessing the students in the context of formal, basic, and even secondary education. The rapid development in the world of education requires teachers to have professional abilities and to master a variety of abilities or competencies as they enable them to carry out their tasks successfully.
In the Indonesian context, teacher competencies include pedagogical, personality, social, and professional ones (Arifin et al., 2020; Baumert \& Kunter, 2013; Muhibbin, 2010). Teachers who can master these four competencies can develop teacher professionalism and change society in the education sector so that the learning activities they conduct become better and thus making the quality of education in Indonesia increase (Suciu \& Mata, 2011). Unfortunately, the competency of teachers in most of the Indonesian regions is considered relatively low. This is based on the survey conducted by the Ministry of Education and Culture summarizing that in most regions of Indonesia, the results of the Teacher Competency Test (UKG) are still concerning, below the minimum competency standards set. Based on these UKG results, the achievement of the national average is only 53.02 which is below the minimum competency standard set of 55.00.

Corresponding Author e-mail: anikghufron@uny.ac.id https://orcid.org/0000-0001-6711-3606

How to cite this article: Erviana, V.Y., Ghufron, A., Haryanto. (2021). The Level of Understanding towards Teachers Competency among Elementary School in Urban Areas of Yogyakarta. Pegem Journal of Education and Instruction, Vol. 11, No. 4, 2021, 360-369

Source of support: Nil

Conflict of interest: None.

DOI: $10.47750 /$ pegegog.2021.66

Received: 13.06.2021

Accepted: 21.09.2021 Publication: 01.10.2021 
One of the factors causing teacher competence in Indonesia is relatively low is because of the uneven distribution of teachers in urban, rural, and urban areas. The remoteness of a certain area will cause obstacles and difficulties in the implementation of the education system (Sher \& Sher, 1994). Mentioned that the implementation of education in urban areas face such obstacles as the limitations of educational facilities and infrastructure [10]. The lack of educational facilities and infrastructure and the limited number of professional teacher development programs make it difficult for the teachers to be able to improve and maintain their quality which then causes education in remote areas to be far behind in quality (Arnold, 2001; Gándara et al., 2001). Basic education in rural and urban areas can be seen from three main perspectives, namely equality of access where everyone can access education, input in the learning process, and learning outcomes achieved in a learning process. Inequality of opportunity will damage the long-term prospects for the development of basic education inequalities from lack of funds, the effectiveness of teachers' incompetence, governance interventions, policy formation, social mobility, and social stratification (Lindfors \& Hilmola, 2016). The low level of basic education competency in rural areas shows the level of quality of rural schools that are still low.

The distribution of teachers in Yogyakarta urban areas is uneven because more qualified teachers are often placed in urban areas so there are fewer teachers available in rural areas. Moreover, most teachers prefer working in urban area places as they assume that in urban areas, the availability of facilities and infrastructure is better, more adequate, and they get more attention as the government favor education in cities rather than rural or urban areas. Also, teachers in urban areas tend to have low-quality education as indicated by a large number of elementary school teachers who are graduates of only high school level. One of the research informed that 1608 teachers in East Kotawaringin are teachers with an only a high school education background. Unfortunately, these high school graduate teachers are commonly found to teach in various elementary schools in rural areas of East Kotawaringin. The condition in Yogyakarta is slightly similar. Unlike East Kotawaringin with its high school graduate teachers, fortunately, most elementary school teachers in Yogyakarta are university graduates. However, instead of majoring in elementary teacher education, these teachers are from various majors. With an educational background that is barely linear, it causes many teachers to not understand and master the concept of teacher competence. Moreover, the delay in information flow in urban areas makes education in these areas hindered from the process of selecting or getting new teachers. As a result, the education quality in urban areas becomes far left behind (Arnold, 2001; Gándara et al., 2001). Seeing this situation, it's needed a kind of assessment of the level of understanding towards the teacher competence among elementary school teachers in Yogyakarta urban areas. This research, therefore, tries to describe the extent of understanding of teacher competence among elementary school teachers in the Yogyakarta urban areas.

\section{Method}

\subsection{Research design}

This research is included in the type of descriptive research describing the level of understanding of teacher competence among elementary school teachers in the urban areas of Yogyakarta.

\subsection{Participants}

Samples were taken randomly mounting to as many as 56 elementary school teachers teaching in the Berbah area cluster in Yogyakarta. Characteristics of the participants in this study were teachers who did not receive much training on competency development for elementary school teachers.

\subsection{Data collection tools}

The data collecting techniques used were questionnaires and interviews. The questionnaire was used to describe the level of understanding of the four teacher competencies. The questionnaire filled by respondents included an understanding of professional, pedagogical, social, and personality competencies involving a rating scale of 1-4: understanding well (4), understanding (3), lack of understanding (2), and not understanding (1).

The grid to see the level of understanding of the teacher competency is displayed as follows in Table 1.

\subsection{Data analysis}

This study uses descriptive statistics to describe the data. Data analysis in this study compared the score of the questionnaire with the criteria. The standard deviation criteria for determining teacher competence is as follows in Table 2.

The results of the interview were used as the additional data to dig deeper into the results of research related to competencies that are not yet understood by the teacher. Meanwhile, for the data analysis, it's used the RASCH WinstepsV3 model.

\section{FINDINGS}

The Level of Elementary School Teachers Understanding Toward Teacher Competency

This section, it is explained the results of research and at the same time is given the comprehensive discussion. Results can be presented in figures, graphs, tables, and others that make the reader understand easily (Okeke \& Mtyuda, 2017). The discussion can be made in several sub-chapters. The results of the 2018 PISA study showed that there are at least five quality teachers in Indonesia that are considered to be able to hinder 
Table 1: Grid Level of Understanding among Elementary School Teachers

\begin{tabular}{|c|c|c|}
\hline Competency & Indicator & Item \\
\hline $\begin{array}{l}\text { Professionals } \\
\text { (K 1- K10) }\end{array}$ & $\begin{array}{l}\text { Mastering the foundation of education in elementary school } \\
\text { Understanding the psychology of the development of elementary school students } \\
\text { Mastering learning materials in elementary school } \\
\text { Understanding the types of learning strategies } \\
\text { Designing innovative and creative media and learning resources } \\
\text { Using media and learning resources in the learning process } \\
\text { Evaluating the learning process according to the indicators and learning objective } \\
\text { Having the ability to compile learning programs } \\
\text { Having the ability to carry out supporting elements } \\
\text { Having the ability to conduct research and think scientifically }\end{array}$ & $\begin{array}{l}1 \\
2 \\
3 \\
4 \\
5 \\
6 \\
7 \\
8 \\
9 \\
10\end{array}$ \\
\hline $\begin{array}{l}\text { Pedagogics } \\
(\text { K } 11-\text { K } 22)\end{array}$ & $\begin{array}{l}\text { Understanding the characteristics of elementary school students } \\
\text { Mastering the types of learning theories and principles of learning in elementary school } \\
\text { Developing curriculum related to subjects in elementary school } \\
\text { Organizing educational learning situations and conditions } \\
\text { Using ICTs in the learning process } \\
\text { Facilitating students to develop their talents } \\
\text { Communicating effectively, empathically, and politely with students } \\
\text { Conducting an evaluation/evaluation of the learning process } \\
\text { Taking reflective actions to improve the quality of learning }\end{array}$ & $\begin{array}{l}1 \\
2-3 \\
4,12 \\
5 \\
6 \\
7 \\
8 \\
9 \\
10-11\end{array}$ \\
\hline $\begin{array}{l}\text { Personality } \\
\text { (K } 23 \text { - K 28) }\end{array}$ & $\begin{array}{l}\text { Acting consistently by religious, legal, social and cultural norms } \\
\text { Presenting themselves as a powerful, stable, mature, wise, and authoritative person in the school and community } \\
\text { environment } \\
\text { Presenting themselves as individuals who have noble character and role models for students in the community } \\
\text { Behaving honestly and be respected by students, colleagues, and superiors } \\
\text { Evaluating yourself on an ongoing basis by learning from a variety of available sources } \\
\text { Upholding the code of ethics of the teaching personal }\end{array}$ & $\begin{array}{l}1 \\
2 \\
3 \\
4 \\
5 \\
6\end{array}$ \\
\hline $\begin{array}{l}\text { Social } \\
\text { (K } 29 \text { - K 32) }\end{array}$ & $\begin{array}{l}\text { Communicating and get along with students } \\
\text { Communicating and get along effectively with fellow educators and education personnel } \\
\text { Communicating and getting along effectively with parents/guardians of students and the community } \\
\text { Mastering the structure and scientific methods to support the learning process in elementary schools }\end{array}$ & $\begin{array}{l}1 \\
2 \\
3\end{array}$ \\
\hline
\end{tabular}

Table 2: Elementary Teacher Competency Criteria

\begin{tabular}{lll}
\hline Standard Deviation & Range & Criteria \\
\hline $\mathrm{X}>\mathrm{Mi}+1.5 \mathrm{Sbi}$ & $182-224$ & Understanding well \\
$\mathrm{Mi}+0.5 \mathrm{Sbi}<\mathrm{X} \leq \mathrm{Mi}+1.5 \mathrm{Sbi}$ & $154-183$ & Sufficiently Understanding \\
$\mathrm{Mi}-0.5 \mathrm{Sbi}<\mathrm{X} \leq \mathrm{Mi}+0.5 \mathrm{Sbi}$ & $126-153$ & Lack of Understanding \\
$\mathrm{Mi}-1.5 \mathrm{Sbi}<\mathrm{X} \leq \mathrm{Mi}+(-0.5) \mathrm{Sbi}$ & $98-125$ & Don't Understand \\
\hline
\end{tabular}

learning, namely: 1. Teachers do not understand student learning needs. 2. Teachers are often absent. 3. Teachers tend to reject the change. 4 . Teachers do not prepare to learn well. 5. Teachers are not flexible in the learning process. Based on this, it implies that every professional teacher in Indonesia must have certain competency standards. Professional standards seek to describe the trust, knowledge, understanding, and ability of teachers as practitioners in the field of education (Ingyarson, 1998). Professional standards in other countries, such as Jordan, the namely professional competence where teachers can develop curriculum and can meet a teacher's spending standards (Mathekga, 2006; McBride, 2007). The learning process can be said to be successful if the teacher can evaluate the learning process according to indicators and objectives learning. This process involves analyzing the needs of students by the learning objectives or based on learning tasks based on ideas, with evaluations conducted through self-reflection and assessment of the process as a solution, 
both individually or in groups to find out how students understand the material delivered by the teacher towards students (Lindfors \& Hilmola, 2016).

The problems of education in Indonesia include inequality in teacher competence and disparity in education in Indonesia is still high. This educational disparity is caused by the fact that city schools are always perceived as superior or favorite schools, but not with urban schools which are perceived as not favorite. Favorite schools are usually filled with students whose achievements and learning are classified good or high and generally have a good family background as well economic and social status. In addition to student disparities, teacher disparities are also still high. Due to this, there is a need for equal distribution of teachers in both urban and city schools.

The results of another study also showed the imbalance of teachers in urban and city schools (Firdaus et al., 2018). The demands of teaching for teachers in urban areas are more severe than those of the teachers who teach in cities areas. This obstacle is triggered by the problems of the lack of facilities and infrastructure to support the learning process in urban areas. The results of interviews with teachers in Berbah urban area Yogyakarta revealed some facts such as the teachers in urban areas tend to get less attention, the system of teacher recruitment in urban areas is not good either. Usually, a teacher who is placed in an urban area is not someone who is an expert in his field. It's quite often that a teacher in an urban area is someone with limited knowledge and teaching skills. This happens merely because the teacher who is recommended to teach there is barely an expert in the field so it causes the learning process to not run optimally.

Environmental conditions and the conditions of people in urban areas, especially in Berbah Yogyakarta, are also obstacles in the process of education. In that area, there has not been as much development as in city areas, especially in the form of road construction (road improvement). The impact of this, among others, is that the progress in the quality of education in such a remote area like Berbah is hindered as well. Putting these all together, the existing problems have caused the elementary school teacher competencies in remote areas aren't the same as those of teachers in cities areas.

To solve the problem, schools must also provide adequate and good learning facilities so teachers feel comfortable in carrying out the teaching and learning process and so that in the future they can acquire such qualities as in aspects of mentality and personality. Besides, the complete learning facilities for students are useful to build and improve their independence in accessing additional learning materials in addition to the ones provided by their teachers or their textbooks. Therefore, it can be concluded that it's not only the government's responsibility to play the role to advance education in urban areas, but also it becomes the role and

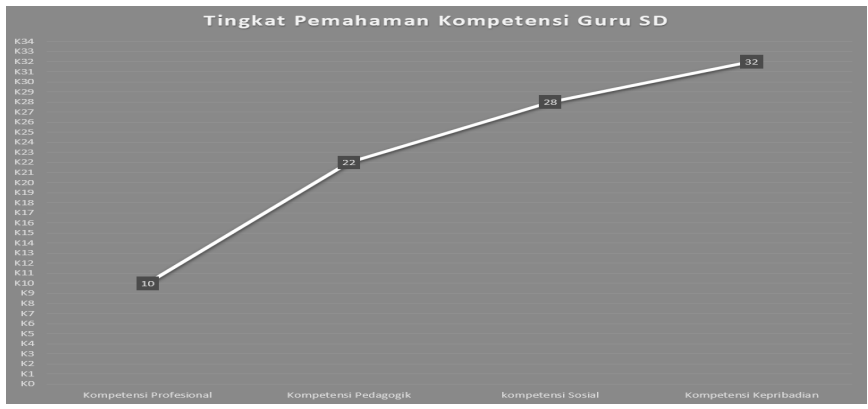

Figure 1: Graphic on the level of elementary school teachers' understanding toward teacher competency

awareness of the society to make betterment in education especially in urban areas.

To better understand the understanding of elementary school teacher competencies, the researchers analyzed the data using the RASCH WinstepsV3 model. The results can be seen in the graph below.

From Figure 1, it can be seen that the lowest level of understanding of elementary school teacher competencies is bound to professional competence. From the survey results of teacher competency, it showed that there were 2 indicators on professional competence that were poorly understood by teachers, i.e. $\mathrm{K} 1$ and $\mathrm{K} 10 . \mathrm{K} 1$ relates to theories about elementary teacher education foundations. In the interview, teachers said they had difficulty in understanding theories related to educational foundations, such as human nature theory, value theory, learning theory, maturity theory, environmental theory, social interdependence theory, transmission theory, and community theory. Whereas $\mathrm{K} 10$ is related to research and scientific thinking in improving performance. In this indicator, the teachers explained that research and scientific thinking were used for promotion, and they didn't do it much. From a theoretical point of view, it's obvious that the quality of teachers in urban areas is still far from the expectations, thus, a training model is needed to help them understand the competencies required for the elementary school teachers. This theory is reinforced by the results of the interview with some of the elementary school teachers who stated that the most difficult competency to understand is the competency to conduct research and to think scientifically. Furthermore, based on the results of the interview, they also said that another ability that is considered difficult to understand is to assess or evaluate the learning process and to take reflective action to improve the quality of learning. However in fact, according to, high teacher professional competence will further enhance teacher activity in teaching.

\section{Professional Competence}

The detail description of the level of professional competence is presented in the following chart: 


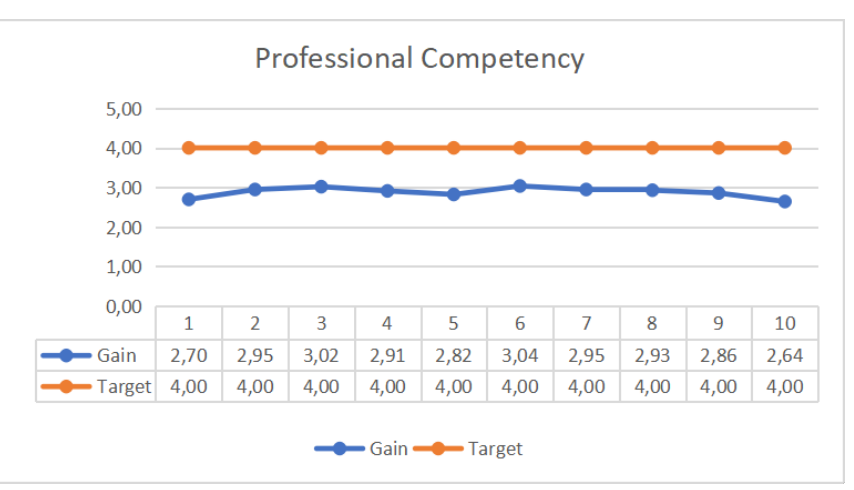

Figure 2: Average Score of Professional Competency

Based on Figure 2, it can be seen that the average score of professional competence is 3.10 . These results indicate that in general, the understanding level of professional competencies among elementary school teachers in the urban areas of Yogyakarta was in the "understand" category. Indicators categorized as "understanding" included: indicator II score was 2.95 with respondent responses of $73.66 \%$, indicator III score was 3.02 with respondent responses of $75.45 \%$, indicator IV score was 2.91 with respondent responses of $72.77 \%$, indicators $\mathrm{V}$ score was 2.82 with respondent responses of $70.54 \%$, indicator VI score was 3.04 with respondent responses of $75.89 \%$, indicator VII score was 2.95 with respondent responses of $73.66 \%$, indicator VIII score was 2.93 with respondent responses of $73,21 \%$, and indicator IX scores were 2.86 with respondent responses of $71.43 \%$. Meanwhile, indicators categorized as "lack of understanding" included: indicator I (score 2.70 with respondent responses of 67.41\%) and indicator $\mathrm{X}$ (score 2.64 with respondent responses of $66.07 \%$ ).

\section{Pedagogical Competence}

The detail description of the level of pedagogical competence is presented in the following chart:

Based on Figure 3, it is found out that the average score of teachers' understanding of the pedagogical competence is 2.92. These results indicate that in general the pedagogical competence of the elementary school teachers in the urban areas of Yogyakarta was in the category of "understanding". Indicators categorized as "understanding well" were indicator XII with a score of 3.57 with respondents' responses of $89.29 \%$. Indicators categorized as "understanding" included: indicator I (score 3.05 with respondent responses of $76.34 \%$ ), indicator III (score 2.88 with respondent responses of $71.88 \%$ ), indicator IV (score 2.77 with respondent responses of 69.20\%), indicators $\mathrm{V}$ (score 3.05 with respondents responses of $76.34 \%$ ), indicator VII (score 2.96 with respondent responses of $74.11 \%$ ), indicator VIII (score 2.91 with respondent responses of $72.77 \%$ ), and indicator IX (score 2.91 with respondent responses of 72,77\%). Meanwhile, indicators categorized as "lack of understanding" included: indicator II (score 2.64 with respondent responses of

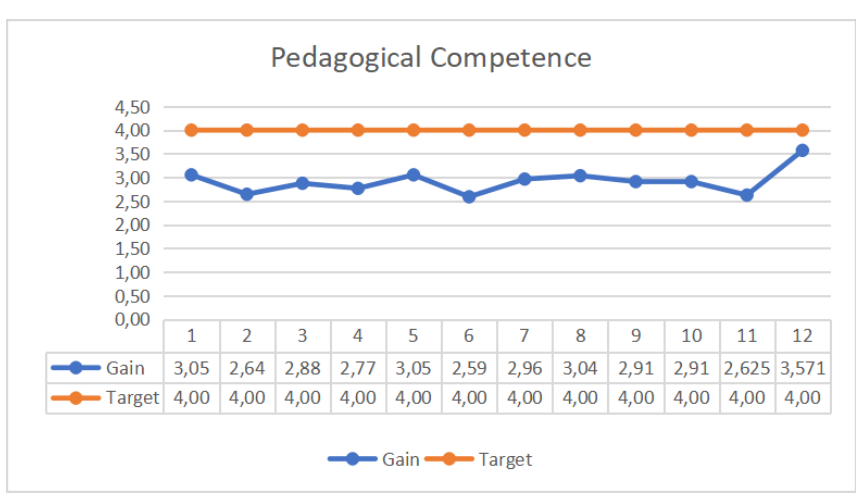

Figure 3: Average Score of Pedagogical Competence

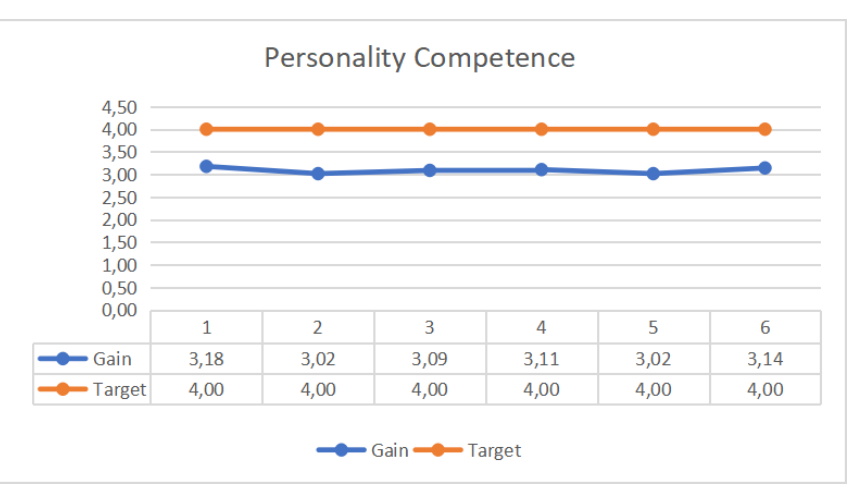

Figure 4: Average Score of Personality Competence

$66.07 \%$ ), indicator VI (score 2.59 with respondents of $64.73 \%$ ), and indicator $\mathrm{X}$ (score 2.63 with respondents of $65.63 \%$ ).

Pedagogical competence is found in indicators K 11- K 22. Figure 2 shows that K $23-\mathrm{K} 28$ which are related to personality competencies are understood more easily by the teachers.

\section{Personality Competence}

The detail description of the level of personality competence is presented in the following chart:

Based on Figure 4, it can be seen that the average score of personality competence is 3.09 . These results indicate that in general, the level of the personality competencies of elementary school teachers in the urban area of Yogyakarta is in the "understand" category. All indicators have the category of "understanding" which included: indicator I (score 3.18 with respondents' responses of 79.46\%), indicator II (score 3.02 with respondents' responses of 75.45\%), indicator III (score 3.09 with respondents' responses of $77.23 \%$ ), indicator IV (score of 3.11 with respondent responses of $77.68 \%$ ), indicator $\mathrm{V}$ (score 3.02 with respondent responses of 75.45\%), and indicator VI (score 3.14 with respondent responses of $78.57 \%$ ).

\section{Social Competence}

The detail description of the level of social competence is presented in the following chart: 


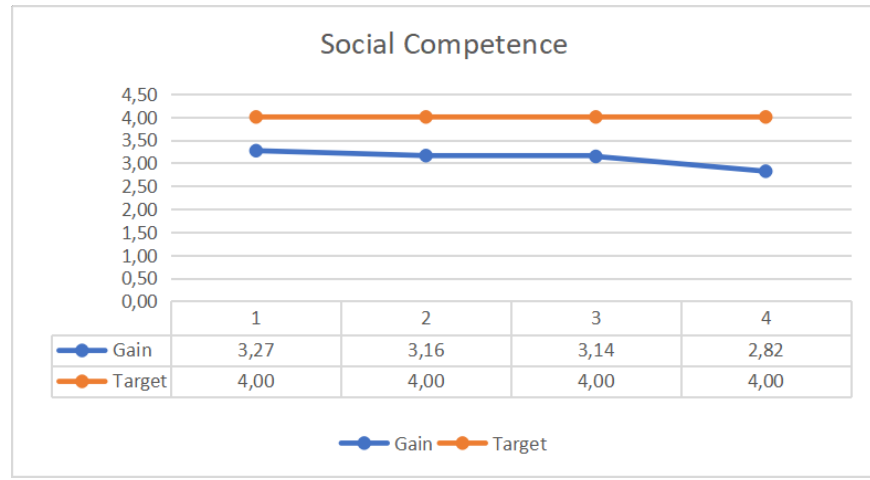

Figure 5: Average Score of Social Competence

Based on Figure 5, it is known that the average score of social competence is 3.10 . These results indicate that in general, the personality competencies level of elementary school teachers in the urban area of Yogyakarta is in the "understand" category. The indicator with a category of "understanding well" included indicator I which scored 3.27 with respondents' responses of $81.70 \%$. The indicator with a category of "understanding" included indicator II which scored 3.16 with respondents' responses of $79.02 \%$, indicator III scored 3.14 with respondents' responses of $78.57 \%$, and indicator IV scored 2.82 with respondents' responses of $70.54 \%$.

\section{Discussion}

Education in Indonesia is an important part of advancing human resources. Every school member has an important role to play in creating a good school climate that supports academic performance and students' self-regulated learning abilities (Saputra et al., 2020; Saputra, Alhadi, et al., 2021). Therefore, teachers need to have good competence in providing learning to students. In Indonesia, there are four teacher competencies, namely pedagogic, professional, social, and personality competencies.

The first competence of teacher in Indonesia is professional competence. Teacher professional competence is very important to help students in building their skills in doing the scientific thinking process. Moreover, professional competence helps improve teachers' understanding starting from mastering the foundation of elementary school education, understanding the psychology of student development, mastering learning material with various types of strategies by designing media and learning resources so that they can assess and evaluate the learning process by the indicators and learning objectives set (Krokfors et al., 2011). The ability of teachers to use local wisdom is also a form of professional competence (Saputra, Mappiare-AT, et al., 2021).

The results of research conducted in the United States informed that teachers' professional development must meet the stated standards (Stiles \& Loucks-Horsley, 1998). There are four standards of teacher professional development standards, namely: 1) Professional development standards A is the professional development in which teachers carry out a process observing natural phenomena, making explanations and testing those explanations based on natural phenomena; 2) Professional development standard $B$ is that professional development for science teachers requires the integration of scientific knowledge into learning; 3) Professional development standard $\mathrm{C}$ is professional development where new knowledge is always generated so that the teacher has the opportunity to continue to learn; 4) Professional development standards are professional programs for science teachers to be coherent (related) and integrated (Darling-Hammond, 2010; Helm, 2015; Roelofs \& Sanders, 2007; Vermunt \& Verloop, 1999).

The second competence of teacher in Indonesia is pedagogical competence. Pedagogical competence that must be understood by the teacher includes the ability to communicate effectively and politely, and conduct evaluation or reflection activities as this reflection did through a self-reflection and evaluation of the learning process can be used as a solution to solve problems that are not yet understood by students (Lindfors \& Hilmola, 2016). Pedagogical competence can be described as the ability and willingness to regularly apply attitudes, knowledge, and skills that encourage learning based on the learning objectives and frameworks and done through the development of sustainable teaching (Puspitasari, 2016). This process must be done in line with the objectives and existing framework and presupposes a sustainable development of the teacher's competency. Furthermore, this competency is closely related to the three important factors of education, namely educational achievement, professional development, and community change. İn addition to being required to master the subject matter well, teachers are supposed to be able to communicate the material in a good manner and strategy (Asmiyati, 2018), so that it can be understood and mastered by the students (Orji, 2012). The lack of teachers' understanding of pedagogical competence must be assessed first such as whether the teacher's educational background is eligible or not because teachers who have teacher education major as their background have better knowledge about classroom management, teaching and learning processes, and the related stuff. On the contrary, teachers with non-teaching major backgrounds tend to have not much knowledge of teaching. Other causes of teachers in pedagogical competence involve things such as teachers' experience in teaching, impaired teacher health, low teacher's income which is said to be triggering the teacher's lack of enthusiasm in carrying out their duties, low education facilities, low discipline in work and low supervision from the school principals.

The third competence of teacher in Indonesia is personality competence. Personality competence is related to how teachers can evaluate themselves continuously by learning 
from various available sources, one of which is that teachers must be open to criticism and suggestions from students, fellow teachers, parents, and community that can be used as a means to evaluate themselves. Furthermore, criticism and suggestions can also be used as a way of having a broad perspective, being confident, and being creative and loving (Saçlı et al., 2009). Also, based on the results of the interview, it's found out that personality competence included the ability to understand easily and to communicate effectively, empathically, and politely with the students. These abilities were also included in social competence which was categorized into items K 29 - K 32. Meanwhile, items K 11 - K 22 were related to pedagogical competence in terms of planning, implementing, and evaluating teaching. Also, the researchers wanted to know the extent of the teacher understanding in pedagogical competence starting from how to understand the characteristics of elementary school students including mastering various characteristics of elementary school students both low and high class, mastering the types of learning theories and principles of learning in elementary teachers, understanding such theories as cognitivism, constructivism, behaviorism, humanistic and social, developing curriculum related to subjects in elementary school. School curriculum is planned and developed by teachers, principals, and educational elements by the core curriculum of the national basic education, which regulates pedagogical activities with a variety of local interpretations (Simola et al., 2017; Toom \& Husu, 2016), and any changes in school curriculum will depend on the competence and expertise of the teachers (Darling-Hammond, 2010). Therefore teachers must be able to organize learning situations and conditions of education by utilizing technology or facilities in schools. The learning environment must support the use of teaching and learning processes as well so it can create spaces or environments to facilitate learning, develop students through their talents by their development such as playing, working in groups, and feeling or doing something directly to prepare an effective and meaningful learning process (Kuuskorpi, 2014).

Teachers can be said upholding the code of ethics of the teaching profession because teachers can improve students' leadership and confidence, increase love and respect for the environment and themselves, help comply with school and classroom rules, and reflect behaviors such as being a role model for the students, behave honestly and be respected by students, colleagues, and authorities. This personality competency is known to be related to the ability of teachers to act consistently by religious, legal, social, and cultural norms. Personality competence is all good personality which has a strong effect on the school situation and classroom atmosphere (Nellitawati, 2017). Teachers who have good personalities can behave according to the existing situations, conditions, and regulations to show their thinking and enhance creativity and personality consisting of physical, intellectual, social, emotional, and moral aspects. Also, teacher personality competency can manifest its presence in individuals who are capable, stable, mature, wise, and authoritative in the school and community environment. Teacher personality competence is reflected through the ability of teachers who show good personality, stable, mature, skilled, and powerful. And they can be a model for students and show wise and responsible attitude (Ünlü et al., 2008). This competency plays an important role in the development of teachers' personalities so that they can prepare and improve human resources and community welfare, as well as the nation and national development (Nellitawati, 2017). Presenting teacher-self as a person of noble character and role model for the students in the community is a reflection of the teachers' personality competency which in turn can be used as an information source to know their particular fields for individual workgroups and features through which professional knowledge is evaluated.

The last competence of teacher in Indonesia is social competence. In the teaching profession, there are several conditions that form the basis of social competence such as: First, the main job of the teacher is to provide guidance in learning, which is an interactive social process. Teachers need to observe the learning process in class, create social situations that support learning activities, and maintain good relationships with students and their parents. Second, teaching social skills to students, which makes learning and teaching these skills a basic activity in teacher education (Murray \& Male, 2005). Third, the teaching profession has changed a lot and developed from pure teaching activities into activities with a variety of collaborative tasks where shared expertise and social skills are essential.

Teachers can be said to have mastered social competence when they can communicate and mingle with students, fellow educators, parents/guardians of students, and the community effectively by mastering scientific structures and methods to support the learning process in elementary schools. To be able to create these qualities, teachers must know how to make communication to ensure the teaching and learning process goes well, not only in the school environment but also with the community. Teachers with better social competence interact positively with others, they will be better prepared at school, make adjustments more easily, and ultimately succeed academically to a greater degree both in the school and community environment (Durlak et al., 2011; Zins et al., 2007). It is not surprising that training and teaching strategies that support teachers are often recommended as a relatively costeffective method of improving social competency outcomes for education (Webster-Stratton et al., 2001). This explains how teachers develop trust in their roles and responsibilities in developing social competence during their teaching experience at school. It's also related to teachers' beliefs in 
accepting their roles and moving forward and backward on the continuum of interventions needed. Although awareness of the development of social competence is very important, however, if teachers do not have awareness and do so to improve social competence in themselves teachers can be said to have not been able to master these competencies (Appl \& Spenciner, 2008). The most important contribution teachers can make to social competence is to build personal, caring, responsive relationships with each student because such relationships with teachers are to build positive relationships with others and then develop positive approaches to learning.

Encouraging the development of social competence has a positive effect on many behaviors and experiences, minimizing risk behaviors, significantly improving the quality of relationships with students, fellow teachers and parents/ guardians, and the community (Markuš, 2010). Teaching about social skills as one of the important characteristics of developing social skills through friendship, empathy, cooperation, mediation, sharing and resolving conflicts, will enable collaboration and partnership relationships. Interaction with students contributes to collaborative learning, management skills, the development of prosocial behavior, emotional security, love, affection, intimacy, solidarity and all are the basis of all relationships (Buljubašić-Kuzmanović, 2010). The development of social skills is one of the prerequisites for creating a favorable emotional climate in the classroom, creating a stimulating environment for learning so that it can be concluded that students become more successful in their academic education (Bognar \& Kragulj, 2010).

Based on this research, there are two competencies with indicators of not understanding. Therefore, further training is needed regarding these competencies so that teachers in Indonesia can be on par with competent and professional teachers worldwide. Teachers in the urban areas of Yogyakarta are said to be lacking in understanding teacher competencies and this should be a concern for educational institutions in equalizing or facilitating teachers so that they can understand and apply or evaluate the mastery of teacher competence in the ongoing teaching and learning process.

\section{Conclusion}

The research results show that the level of elementary school teachers' understanding of teacher competencies can be ranked starting from the lowest levels as follows: professional competence, pedagogical competence, social competence, and personality competence. Teacher competencies that are not yet understood by teachers in the Yogyakarta urban area are professional and pedagogical. Professional competence that is not yet understood is related to the ability to understand theories about elementary education foundation and to conduct research and scientific thinking process. Professional competence helps improve teacher understanding ranging from mastering the foundation of elementary school education, understanding the psychology of student development, mastering learning materials with various types of strategies by designing media and learning resources so that they can evaluate the learning process by indicators and learning objectives. Whereas pedagogical competence is not yet understood in the types of learning theory, the use of ICT in the learning process, and planning of learning before teaching in the class. Pedagogical competence can encourage learning from learning objectives and frameworks through the development of sustainable teaching in the best way. Meanwhile, the competencies that have been understood by teachers in urban areas include social competence and personality. Teachers who have better social competence interact positively with others, they will be better prepared at school and have good personalities and can be role models for students and their environment. After all, all aspects of competency must be understood by a teacher because it has a big impact on the professionalism of a teacher.

\section{SUGgestion}

This study recommends further research to be able to identify teacher competencies in Indonesia more broadly. This has the aim of being able to carry out a wider portrait of teacher competence in Indonesia. The results of this study also recommend teachers in Indonesia to improve their competence, both pedagogically, professionally, socially, and personally through various trainings.

\section{LimitaTION}

This research is limited to only 5 schools in urban areas in Sleman Regency. This is because the Yogyakarta area shows remote elementary schools, especially in Sleman Regency, in the sample schools.

\section{References}

Amin, J. N. (2016). Redefining the role of teachers in the digital era. The International Journal of Indian Psychology, 3(3), 40-45. https://doi.org/10.25215/0303.101

Appl, D. J., \& Spenciner, L. J. (2008). What do pre-service teachers see as their roles in promoting positive social environments?"I see myself as a facilitator of acceptance". Early Childhood Education Journal, 35(5), 445-450. https://doi.org/10.1007/ s10643-007-0188-1

Arifin, Z., Nurtanto, M., Priatna, A., Kholifah, N., \& Fawaid, M. (2020). Technology Andragogy Work Content Knowledge Model as a New Framework in Vocational Education: Revised Technology Pedagogy Content Knowledge Model. TEM Journal, 9(2), 786-791. https://doi.org/10.18421/TEM92-48

Arnold, P. (2001). Review of contemporary issues for rural schools. Education in Rural Australia, 11(1), 30-42.

Asmiyati, A. (2018). Peningkatan Kompetensi Guru PAI dalam Menyusun Rpp Berbasis Saintifik di SD Piyungan Bantul TA 
2016/2017. Jurnal Pendidikan Agama Islam, 15(2), 114-133. https://doi.org/10.14421/jpai.2018.152-02

Ball, D. (2000). Intertwining Content and Pedagogy in Teaching and Learning To Teach. Journal of Teacher Education, 51(3), 241-247. https://doi.org/10.1177/0022487100051003013

Baumert, J., \& Kunter, M. (2013). Professionelle Kompetenz von Lehrkräften. In I. Gogolin, H. Kuper, \& J. Baumert (Eds.), Stichwort: Zeitschrift für Erziehungswissenschaft (pp. 277337). Springer.

Bognar, L., \& Kragulj, S. (2010). Kvaliteta nastave na fakultetu. Život i Škola: Časopis Za Teoriju i Praksu Odgoja i Obrazovanja, 56(24), 169-182.

Buljubašić-Kuzmanović, V. (2010). Socijalne kompetencije i vršnjački odnosi u školi. Pedagogijska Istraživanja, 7(2), 191-201.

Darling-Hammond, L. (2010). Evaluating teacher effectiveness: How teacher performance assessments can measure and improve teaching. Center for American Progress. https://doi. org/10.2307/41497541

Day, C. (2002). School reform and transitions in teacher professionalism and identity. International Journal of Educational Research, 37(8), 677-692. https://doi.org/10.1016/ S0883-0355(03)00065-X

Durlak, J. A., Weissberg, R. P., Dymnicki, A. B., Taylor, R. D., \& Schellinger, K. B. (2011). The impact of enhancing students' social and emotional learning: A meta-analysis of school-based universal interventions. Child Development, 82(1), 405-432. https://doi.org/10.1111/j.1467-8624.2010.01564.x

Firdaus, F., Sulfasyah, S., \& Nur, H. (2018). Diskriminasi Pendidikan Masyarakat Terpencil. Equilibrium: Jurnal Pendidikan, 6(1), 33-43. https://doi.org/10.26618/equilibrium. v6i1.1796

Gándara, P., Gutiáez, D., \& O'Hara, S. (2001). Planning for the future in rural and urban high schools. Journal of Education for Students Placed at Risk, 6(1-2), 73-93. https://doi.org/10.1207/ S15327671ESPR0601-2_5

Hamalik, O. (2008). Proses belajar mengajar. Jakarta: Bumi Aksara.

Helm, C. (2015). Determinants of competence development in accounting in upper secondary education. Empirical Research in Vocational Education and Training, 7(1), 1-36. https://doi. org/10.1186/s40461-015-0022-8

Ingyarson, L. (1998). Professional standards: A challenge for the AATE? English in Australia, 122, 31-44.

Krokfors, L., Kynäslahti, H., Stenberg, K., Toom, A., Maaranen, K., Jyrhämä, R., Byman, R., \& Kansanen, P. (2011). Investigating Finnish teacher educators' views on research-based teacher education. Teaching Education, 22(1), 1-13. https://doi.org/10 $.1080 / 10476210.2010 .542559$

Kuuskorpi, M. (2014). PersPectives from finland-towards new learning environments. Finnish National Board of Education: Publications, 1 .

Lindfors, E., \& Hilmola, A. (2016). Innovation learning in comprehensive education? International Journal of Technology and Design Education, 26(3), 373-389.

Markuš, M. (2010). Socijalna kompetentnost-jedna od ključnih kompetencija. Napredak, 151.

Mathekga, A. M. (2006). The impact of in-service training: A reassessment of the cascade model [PhD Thesis]. University of Pretoria.
McBride, S. A. (2007). Review of Special Education-Grades 1-12 Summary. Report Prepared for the Ministry of Education, Hashemite Kingdome of Jordan. ERfKE, 1.

Muhibbin, S. (2010). Psikologi pendidikan dengan pendekatan baru. Bandung: PT Remaja Rosdakarya.

Murray, J., \& Male, T. (2005). Becoming a teacher educator: Evidence from the field. Teaching and Teacher Education, 21(2), 125-142. https://doi.org/10.1016/j.tate.2004.12.006

Nellitawati, N. (2017). The Contribution of Headmaster's Personality Competence to the Teacher's Social competence of Vocational High S. COUNS-EDU: The International Journal of Counseling and Education, 2(1), 25-34. https://doi. org/10.23916/002017027710

Okeke, C. I., \& Mtyuda, P. N. (2017). Teacher Job Dissatisfaction: Implications for Teacher Sustainability and Social Transformation. Journal of Teacher Education for Sustainability, 19(1), 57-68.

Orji, N. S. (2012). A correlational study of Students' Attitude and Achievement in Chemistry with Teacher Classroom Management Behaviours. Journal Of Science, Technology, Mathematics And Education (Jostmed), 8(2), 143.

Puspitasari, W. D. (2016). Pengaruh Sarana Belajar Terhadap Prestasi Belajar Ilmu Pengetahuan Sosial Di Sekolah Dasar. Jurnal Cakrawala Pendas, 2(2). https://doi.org/10.31949/jcp.v2i2.338

Roelofs, E., \& Sanders, P. (2007). Towards a Framework for Assessing Teacher Competence. European Journal of Vocational Training, 40(1), 123-139. https://doi.org/10.1007/978-3-31989945-9

Saçlı, F., Bulca, Y., Demirhan, G., \& Kangalgil, M. (2009). Physical education teachers' personal qualities. Journal of Sports Sciences, 20(4), 145-151.

Saputra, W. N. E., Alhadi, S., Supriyanto, A., \& Adiputra, S. (2021). The Development of Creative Cognitive-Behavior Counseling Model as a Strategy to Improve Self-Regulated Learning of Student. International Journal of Instruction, 14(2), 627-646. https://doi.org/10.29333/iji.2021.14235a

Saputra, W. N. E., Mappiare-AT, A., Hidayah, N., \& Ramli, M. (2021). KH Ahmad Dahlan's the values of peace in the novel entitled Sang Pencerah: A hermeneutics study. Pegem Journal of Education and Instruction, 11(2), 32-42. https://doi. org/10.14527/pegegog.2021.04

Saputra, W. N. E., Supriyanto, A., Astuti, B., Ayriza, Y., \& Adiputra, S. (2020). The Effect of Student Perception of Negative School Climate on Poor Academic Performance of Students in Indonesia. International Journal of Learning, Teaching and Educational Research, 19(2), 279-291. https://doi.org/10.26803/ijlter.19.2.17

Sher, J. P., \& Sher, K. R. (1994). Beyond the conventional wisdom: Rural development as if Australia's rural people and communities really mattered. Journal of Research in Rural Education, 10(1), 2-43.

Simola, H., Kauko, J., Varjo, J., Kalalahti, M., \& Sahlström, F. (2017). Dynamics in education politics: Understanding and explaining the Finnish case. Routledge.

Stiles, K. E., \& Loucks-Horsley, S. (1998). Professional development strategies. The Science Teacher, 65(6), 46.

Suciu, A. I., \& Mata, L. (2011). Pedagogical competences-the key to efficient education. International Online Journal of Educational Sciences, 3(2), 411-423. 
Suryarahman, E., \& Hastuti, H. (2014). Kinerja guru ips smp bersertifikasi profesi berdasarkan standar kompetensi guru di kabupaten lombok utara. Harmoni Sosial: Jurnal Pendidikan IPS, 1(2). https://doi.org/DOI: https://doi.org/10.21831/hsjpi. vli2.2435

Toom, A., \& Husu, J. (2016). Finnish teachers as 'makers of the many'. In Miracle of education (pp. 41-55). Springer.

Ünlü, H., Sünbül, M. A., \& Aydos, L. (2008). Physical education teachers' competence and the validity- reliability study. Journal of Ahi Evren University Faculty of Education, 9(2), 23-33.

Vermunt, J. D., \& Verloop, N. (1999). Congruence and friction between learning and teaching. Learning and Instruction, 9(3), 257-280. https://doi.org/10.1016/S0959-4752(98)00028-0

Webster-Stratton, C., Reid, J., \& Hammond, M. (2001). Social skills and problem-solving training for children with early-onset conduct problems: Who benefits? Journal of Child Psychology and Psychiatry, 42(7), 943-952.

Wilson, J. P. (2014). International human resource development: Learning, education and training for individuals and organisations. Development and Learning in Organizations, 28(2). https://doi.org/10.1108/DLO-02-2014-0010

Wiretna, C. D., Saputra, W. N. E., Muarifah, A., \& Barida, M. (2020). Effectiveness of Solution-Focused Brief Counseling to Reduce Online Aggression of Student. Universal Journal of Educational Research, 8(3), 1092-1099. https://doi. org/10.13189/ujer.2020.080344

Zins, J. E., Bloodworth, M. R., Weissberg, R. P., \& Walberg, H. J. (2007). The scientific base linking social and emotional learning to school success. Journal of Educational and Psychological Consultation, 17(2-3), 191-210. https://doi. org/10.1080/10474410701413145 